Prepared for the U.S. Department of Energy under Contract DE-AC05-76RL01830

\title{
American Recovery and Reinvestment Act (ARRA) FEMP Technical Assistance Federal Aviation Administration Project 209 - Control Tower and Support Building, Oakland, CA
}

\author{
J Arends \\ WF Sandusky
}

March 2010

\section{Pacific Northwest}

NATIONAL LABORATORY

Proudly Operated by Battelle Since 1965 


\title{
DISCLAIMER
}

This documentation was prepared as an account of work sponsored by an agency of the United States Government. Neither the United States Government nor any agency thereof, nor Battelle Memorial Institute, nor any of their employees, makes any warranty, express or implied, or assumes any legal liability or responsibility for the accuracy, completeness, or usefulness of any information, apparatus, product, or process disclosed, or represents that its use would not infringe privately owned rights. Reference herein to any specific commercial product, process, or service by trade name, trademark, manufacturer, or otherwise does not necessarily constitute or imply its endorsement, recommendation, or favoring by the United States Government or any agency thereof, or Battelle Memorial Institute. The views and opinions of authors expressed herein do not necessarily state or reflect those of the United States Government or any agency thereof.

\author{
PACIFIC NORTHWEST NATIONAL LABORATORY \\ operated by \\ BATTELLE \\ for the \\ UNITED STATES DEPARTMENT OF ENERGY \\ under Contract DE-AC05-76RL01830
}

Printed in the United States of America

Available to DOE and DOE contractors from the Office of Scientific and Technical Information,

P.O. Box 62, Oak Ridge, TN 37831-0062;

ph: (865) 576-8401, fax: (865) 576-5728

email: reports@adonis.osti.gov

Available to the public from the National Technical Information Service,

U.S. Department of Commerce, 5285 Port Royal Rd., Springfield, VA 22161

ph: (800) 553-6847, fax: (703) 605-6900

email: orders@ntis.fedworld.gov

online ordering: http://www.ntis.gov/ordering.htm

This document was printed on recycled paper.

$(8 / 00)$ 
PNNL-19389

\title{
American Recovery and Reinvestment Act (ARRA) FEMP Technical Assistance \\ Federal Aviation Administration Project 209 \\ Control Tower and Support Building, Oakland, CA
}

\author{
J Arends ${ }^{(a)}$ \\ WF Sandusky
}

March 2010

Prepared for

U.S. Department of Energy

under Contract DE-AC05-76RL01830

Pacific Northwest National Laboratory

Richland, Washington 99352

(a) Redhorse Corporation 


\section{Executive Summary}

This report represents findings of a design review team that evaluated construction documents (at the $70 \%$ level) and operating specifications for a new control tower and support building that will be build at Oakland, California by the Federal Aviation Administration (FAA). The focus of the review was to identify measures that could be incorporated into the final design and operating specification that would result in additional energy savings for the FAA that would not have otherwise occurred.

The process that was followed in this review was to first identify various measures that should be considered prior to finalization of the construction and operation specifications. Those measures were evaluated by the FAA and a series of recommendations were selected for further evaluation, including estimating the resulting energy savings (electric and gas), cost savings, implementation cost, and simple payback.

A total of 42 recommendations were documented and delivered to the FAA design team. Of that total, six recommendations were selected to be incorporated into the final design document. These included both low-cost and no-cost projects that typically related to operational requirements, as well as capital projects that would result in an actual design change. Implementation of the six measures would result in an electrical energy savings of 170,244 kWh and a thermal energy savings of 443 therms. Based on the present commodity rates, the annual cost savings for the site would be $\$ 18,706$. The total cost for implementation is estimated to be $\$ 42,400$ resulting in a simple payback of 2.3 years.

Project implementation would reduce greenhouse gas emissions to the atmosphere and create jobs for local workers. It is estimated that an emission of 124 metric tons of $\mathrm{CO}_{2}$ to the atmosphere would be avoided by implementation of the measures and 0.5 new jobs would be created. These values would increase if other recommended measures were ultimately integrated into the final design. 


\section{Contents}

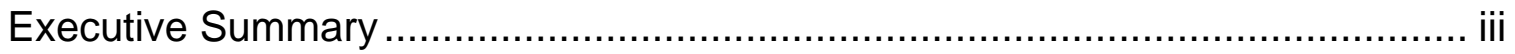

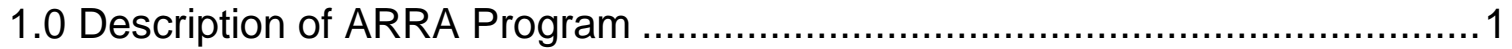

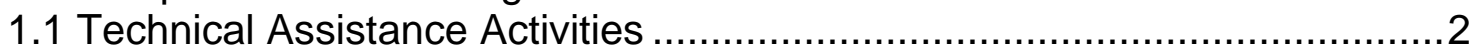

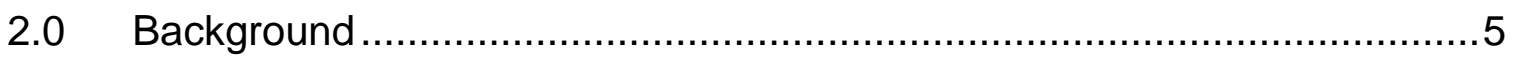

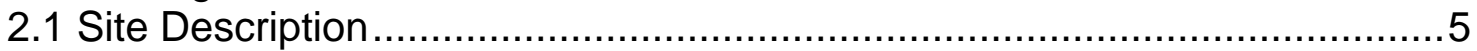

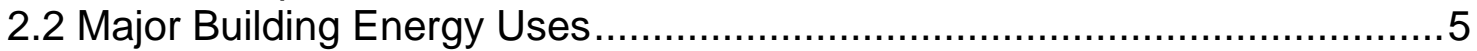

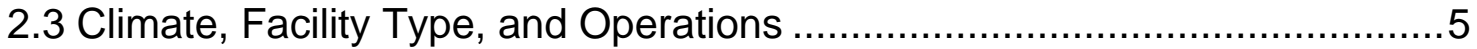

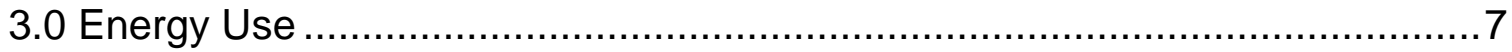

3.1 Current Energy, Gas, and Water Use .............................................. 7

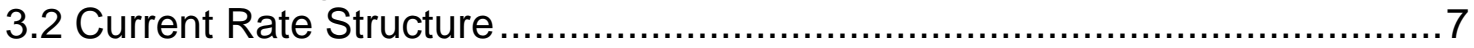

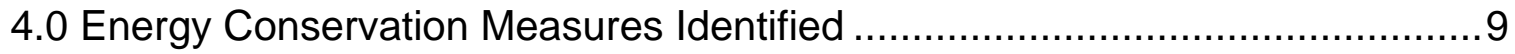

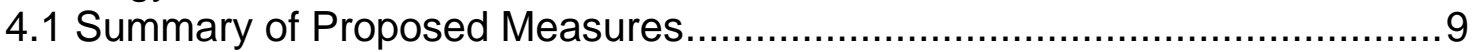

4.2 Renewable Energy Measures Evaluated ........................................... 17

5.0 Potential Green House Gas Reduction ............................................... 19

6.0 Action Plan for Implementation of Energy Conservation Measures (ECMs) . 21

6.1 Priorities and Next Steps ...................................................................

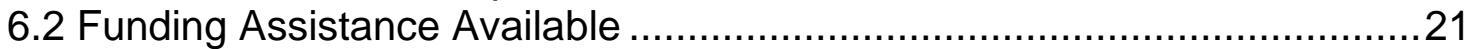

7.0 Assessment Team Members and Site Team ........................................23

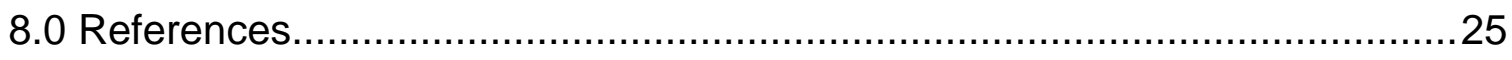

Appendix A - eQUEST Modeling Results and Spreadsheet Calculations ......... A.1 


\section{Figures}

Figure 1 Chiller Power Increase Caused by Condenser Placement Issues ........11

\section{Tables}

Table 1 Summary of Annual Estimated Energy Savings Recommended From

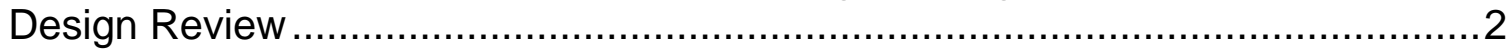

Table 2 Energy Conservations Measures Incorporated in the Final Design

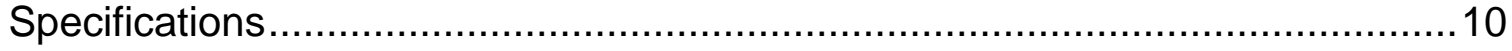




\subsection{Description of ARRA Program}

The Federal Energy Management Program (FEMP) facilitates the Federal Government's implementation of sound, cost-effective energy management and investment practices to enhance the nation's energy security and environmental stewardship. In fiscal year 2009, FEMP received funds specific to the American Recovery and Reinvestment Act (ARRA) of 2009 to assist in the identification, evaluation, documentation of energy efficiency and renewable energy projects at Federal sites.

These funds were allocated to expand the Department of Energy's (DOE's) laboratory and contractor support to agencies and to quickly provide technical advice and assistance to expand and accelerate project activities. FEMP requested that agencies submit projects in need of technical assistance in the following areas:

- Initial screenings or assessments of facility needs and/or feasibility of a particular technology

- Project prioritization

- Strategic energy planning and benchmarking

- Technical reviews of designs and proposals

- Energy audit training

- High-performance green building technical support

- Federal vehicle fleet technical support

- Operations and maintenance

- Detail of key lab staff to work within agencies for a limited duration (normally not more than 24 months)

- All of the above with special emphasis on particular technologies in the areas of the labs' expertise.

The Federal Aviation Administration submitted a response to a FEMP call for projects that was issued on May 1, 2009 requesting that energy audits be conducted at four FAA locations in California with the goal of identifying energy conservation measures that could be implemented in a timely manner. This project was accepted by FEMP and designated as Project 209. After project selection, it was determined that the sites were being considered as part of a larger energy saving performance contracts (ESPC) project, so the scope of the project was changed and divided into two parts. The first part consisted of a technical review of the proposed construction and operating specifications for buildings to be constructed at three airport locations (Las Vegas, NV and Palm Springs and Oakland, CA). The second part requested that energy audits be 
performed at on-going construction activities at two other sites (Reno, NV and Boise, ID). This report represents the findings regarding review of the construction and operating specifications (70\% design level) for the Oakland, CA site. Results of the other reviews will be documented in separate reports.

\subsection{Technical Assistance Activities}

The Pacific Northwest National Laboratory (PNNL) contracted with the Redhorse Corporation to complete a review of construction design and operation specifications to identify additional energy efficiency measures or operating specifications that could be provided to Federal Aviation Administration (FAA) for consideration to meet final design completion timelines. Upon review of the proposed recommendations by the FAA, Redhorse Corporation developed estimates of potential energy savings impacts for those design review comments that will be incorporated in the final design documents. Table 1 summarizes the potential annual energy savings, both gas and electric, associated with the accepted recommendations.

Table 1 Summary of Annual Estimated Energy Savings Recommended From Design Review

\begin{tabular}{|c|c|c|c|}
\hline $\begin{array}{c}\text { Review Comment } \\
\text { Item \# of } 42 \\
\text { Identified } \\
\text { Recommendations } \\
\end{array}$ & Recommendation & $\begin{array}{c}\text { Electrical } \\
(\mathbf{k W h})\end{array}$ & $\begin{array}{l}\text { Natural Gas } \\
\text { (therms) }\end{array}$ \\
\hline & Avoidable Future Increases in Energy Use & & \\
\hline 1 & Outdoor condensing unit location & 10,338 & - \\
\hline \multirow[t]{3}{*}{2} & UV lamp cooling coil treatment & 13,026 & - \\
\hline & Total & 23,364 & 0 \\
\hline & Energy Saving Recommendations & & \\
\hline $3,4,9,10$ & High efficiency motors & 6,700 & 0 \\
\hline 12 & Variable air volume (VAV) Static Pressure Reset & 27,700 & - \\
\hline 16 & Demand-controlled $\left(\mathrm{CO}_{2}\right)$ ventilation & 66,120 & 156 \\
\hline 18 & Chilled water reset 45 to $55^{\circ} \mathrm{F}$ & 16,000 & - \\
\hline 22 & Heating setpoint of $70^{\circ} \mathrm{F}$ instead of $75^{\circ} \mathrm{F}$ & $-2,700$ & 209 \\
\hline \multirow[t]{2}{*}{34} & $\begin{array}{l}\text { Occupancy sensor heating, ventilation and air- } \\
\text { conditioning (HVAC) }\end{array}$ & 33,060 & 78 \\
\hline & Total (Non-Interactive) & 146,880 & 443 \\
\hline
\end{tabular}

The FAA design team used the Carrier Hourly Analysis Program (HAP) to model the energy use of the systems selected for the building. Redhorse review comment items were evaluated for potential energy savings using eQUEST for 
most of the items. The eQUEST model was developed to provide a quick estimate of the energy savings potential and does not include the fine degree of detail included in the design team's Carrier HAP model. The inputs of the eQUEST model were adjusted until annual energy use estimates from the model matched the design team's results.

The eQUEST model was executed using the schematic wizard function to develop a simple model of the building and its systems. However, some of the items were estimated using case studies, and energy savings estimates were extrapolated for this project. Each review item is discussed in the following sections, after the summary table. Some of the suggestions also include a discussion of the challenges associated with implementing the review item.

The first two recommendations will reduce the likelihood that energy use will increase in addition to the energy use projected by the design team's energy models. The remainder of the recommendations provide energy savings if they are implemented in construction of the facilities.

Energy savings estimates represent individual model runs and do not represent the interactive impacts. Interactive impacts on the energy savings would depend on the recommendations selected to be implemented. Interactive energy savings estimates will be less than were estimated as individual runs. 


\subsection{Background}

\subsection{Site Description}

The site is located near San Francisco Bay about eight miles east of the city of San Francisco. This area was originally inhabited by the Ohlone people for thousands of years before being displaced by Spanish settlers in the $18^{\text {th }}$ and $19^{\text {th }}$ centuries. This area was first part of New Spain, but later gaining independence in 1821 as part of Mexico. In 1846, it became what we now know as California.

The area originally consisted of fertile flatland that became a prolific agricultural region and oak and redwood resource area in the hills to the east. The oak and redwoods were logged to build the city of San Francisco. Today, the area is a vast network of business and homes that ultimately support port operations at Oakland. The port area is considered a major west coast terminal supporting more than 200,000 jobs.

\subsection{Major Building Energy Uses}

The major end-use of energy at the building will be lighting, space heating and cooling, and radar and communication equipment.

\subsection{Climate, Facility Type, and Operations}

The climate for the site is considered maritime. Based on data available from the National Climatic Center, the maximum mean monthly temperature occurs in September $\left(74.6^{\circ} \mathrm{F}\right)$, with the minimum mean monthly temperature occurring in January $\left(44.7^{\circ} \mathrm{F}\right)$. The highest recorded temperature during the period from 1970 through 2001 was $109^{\circ} \mathrm{F}$ on September 14, 1971, while the lowest reported temperature during the period of 1970 through 2001 was $26^{\circ} \mathrm{F}$ on December 9 , 1972. Based on the most recent mean data available (1971-2000), the site should experience 6 days with a maximum temperature exceeding or equal to $90^{\circ} \mathrm{F}$ and 1 day with a maximum temperature exceeding or equal to $100^{\circ} \mathrm{F}$. The minimum temperature should be at $32^{\circ} \mathrm{F}$ or below for 1 day annually. Annually, the site should anticipate 2400 heating degree days (HDD) and 377 cooling degree days (CDD).

Mean precipitation level for the site is 22.94 inches per year. The highest daily reported precipitation was 4.74 inches for January 4, 1982. The highest reported monthly precipitation, 15.14 inches, occurred in February 1998. The daily precipitation should be at or greater than 0.01 inches for 65 days during the year. The site has no reported snowfall during the period of $1971-2000$. 


\subsection{Energy Use}

No historical energy use data exists because the building has yet to be constructed.

\subsection{Current Energy, Gas, and Water Use}

Specific information regarding energy, gas, and water use was not obtained because the building has yet to be constructed. Information from the existing facility would not be appropriate for use because that building was constructed under a totally different building code.

\subsection{Current Rate Structure}

The FAA currently pays 13.89 cents per $\mathrm{kWh}$ and $\$ 1.29$ dollars per therm from the providers for the existing building. These values were used in calculating the baseline energy consumption and the incremental savings from the various proposed measures. 


\subsection{Energy Conservation Measures Identified}

The design review team identified a total of 42 energy conservation measures that should be considered by the FAA building design team. This included a variety of measures, operating specifications for equipment, and potential renewable power generation sources. The FAA design team adopted eight measures to be included in the final design. Some of the measures that were accepted were a combination of several recommendations. The measures included both no-cost/low-cost as well as additional capital investment projects. A summary of those measures -- estimated electrical and natural gas savings; associated electric, gas and annual cost savings; along with implementation cost and simple payback calculation -- is provided in Table 2.

\subsection{Summary of Proposed Measures}

Outdoor Condensing Unit Locations: The existence of a screening wall or the wall of a building in close proximity to an air-cooled chiller is common in both rooftop and ground-level applications. Hot air recirculation on the coils adjoining the wall will increase compressor discharge pressure, decreasing capacity and increasing power consumption. Only the compressors connected to these coils will be affected. Circuits opposite the wall are unaffected. When they are close to a wall, it is desirable to place chillers on the north or east side of the walls. It is also desirable to install the units so prevailing winds blow parallel to the unit's long axis. The worst case is to have wind blowing hot discharge air into the wall.

Units installed side by side should not be spaced closer than the limits stated in the installation manual (the space requirement depends on the unit size). If they are installed closer, it is necessary to adjust the performance of each unit. NOTE: This case applies only to two units side by side. If one of the two units also adjoins a wall, there is an additional adjustment factor. Add the two adjustment factors together and apply to the unit located between the wall and the other unit. Mounting units end to end will not necessitate adjusting performance, however. Depending on the actual arrangement, sufficient space must be left between the units for access to the control panel door opening or to remove the evaporator tube.

Energy savings estimates were estimated by spreadsheet calculation and summarized in Table 2. Figure 1 shows a 6\% increase in energy use if the outdoor units are placed within $9 \mathrm{ft}$ of each other's lateral side. 
Table 2 Energy Conservations Measures Incorporated in the Final Design Specifications

\begin{tabular}{|c|c|c|c|c|c|c|c|c|}
\hline $\begin{array}{l}\text { Review } \\
\text { Comment } \\
\text { Item \# }\end{array}$ & $\begin{array}{c}\text { Oakland FAA } \\
\text { Control Tower and } \\
\text { Base Buildings } \\
\text { Energy Saving } \\
\text { Recommendations } \\
\end{array}$ & $\begin{array}{c}\text { Electrical } \\
\text { Savings } \\
\text { (kWH) } \\
\end{array}$ & $\begin{array}{l}\text { Natural } \\
\text { Gas } \\
\text { Savings } \\
\text { (Therms) } \\
\end{array}$ & $\begin{array}{c}\text { Electrical } \\
\text { Savings } \\
(\$) \\
\end{array}$ & $\begin{array}{l}\text { Natural } \\
\text { Gas } \\
\text { Savings } \\
\text { (\$) } \\
\end{array}$ & $\begin{array}{l}\text { Total } \\
\text { Annual } \\
\text { Savings } \\
\text { (\$) } \\
\end{array}$ & $\begin{array}{c}\text { Cost to } \\
\text { Implement } \\
(\$) \\
\end{array}$ & $\begin{array}{c}\text { Simple } \\
\text { Payback } \\
\text { (Years) }\end{array}$ \\
\hline & Cost per unit & & & 0.1389 & 1.2890 & & & \\
\hline & $\begin{array}{l}\text { Low Cost / No } \\
\text { Cost Measures }\end{array}$ & & & & & & & \\
\hline 1 & $\begin{array}{l}\text { Outdoor } \\
\text { condensing unit } \\
\text { location }\end{array}$ & 10,338 & 0 & $\$ 1,436$ & $\$$ & $\$ 1,436$ & 200 & 0.1 \\
\hline 2 & $\begin{array}{l}\text { UV light - cooling } \\
\text { coil treatment }\end{array}$ & 13,026 & 0 & $\$ 1,338$ & $\$$ & $\$ 1,338$ & 2,000 & 1.5 \\
\hline $3,4,9,10$ & $\begin{array}{l}\text { Premium } \\
\text { efficiency motors }\end{array}$ & 6,700 & 0 & $\$ \quad 688$ & $\$$ & $\$ 688$ & 2,200 & 3.2 \\
\hline 12 & $\begin{array}{l}\text { VAV static } \\
\text { pressure reset }\end{array}$ & 27,700 & 0 & $\$ 2,845$ & $\$$ & $\$ 2,845$ & 2,400 & 0.8 \\
\hline 18 & $\begin{array}{l}\text { Chilled water reset } \\
45 \text { to } 55^{\circ} \mathrm{F}\end{array}$ & 16,000 & 0 & $\$ 1,643$ & $\$$ & $\$ 1,643$ & 300 & 0.2 \\
\hline 22 & $\begin{array}{l}\text { Heating setpoint } \\
\text { of } 70^{\circ} \mathrm{F} \text { instead of } \\
75\end{array}$ & $-2,700$ & 209 & $\$$ & $\$ 270$ & $\$ 270$ & 300 & 1.1 \\
\hline & Capital Projects & & & & & & & \\
\hline 16 & $\begin{array}{l}\text { Demand- } \\
\text { controlled }\left(\mathrm{CO}_{2}\right) \\
\text { ventilation }\end{array}$ & 66,120 & 156 & $\$ 6,791$ & $\$ 201$ & $\$ 6,992$ & 20,000 & 2.9 \\
\hline 34 & $\begin{array}{l}\text { Occupancy sensor } \\
\text { HVAC }\end{array}$ & 33,060 & 78 & $\$ 3,395$ & $\$ 101$ & $\$ 3,496$ & 15,000 & 4.3 \\
\hline & $\begin{array}{l}\text { Total (Non- } \\
\text { interactive) }\end{array}$ & 170,244 & 443 & $\$ 18,136$ & $\$ 571$ & $\$ 8,706$ & 42,400 & 2.3 \\
\hline
\end{tabular}




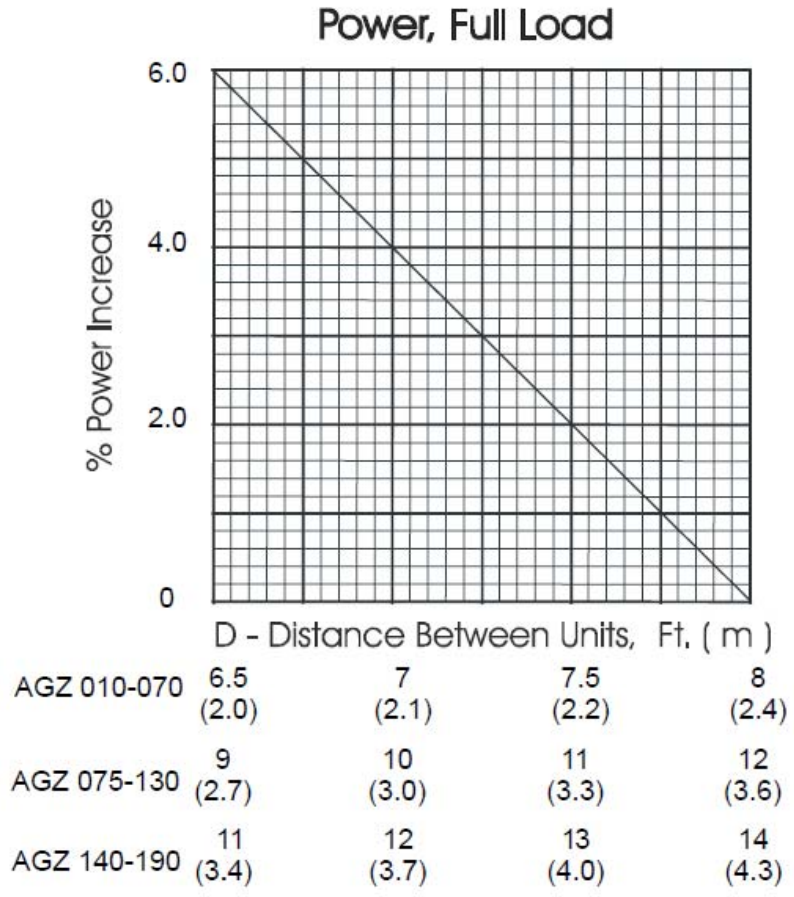

Figure 1 Chiller Power Increase Caused by Condenser Placement Issues

UV Light - Cooling Coil Treatment: Energy savings resulting from the installation of UV cooling coil treatment systems can be estimated by comparing the operating costs of systems with and without UV treatment systems. Field data from systems operating without the use of UV treatment suggest that there is an increase in fan energy use caused by the buildup of debris on the air side of the cooling coils. Several months after a UV cooling coil treatment system is installed, cooling coil surfaces are cleaner and the fan energy use decreases as the static pressure decreases. In addition to the fan energy losses, the bacterial debris on the surface of the cooling coil cause a fouling effect on the heat transfer from the coils. Fouling of the heat transfer surface reduces the heat transfer efficiency. When UV treatment is installed on new systems, the energy savings is estimated on the basis of the projected fouling of the cooling coil surfaces as it affects air flow resistance and heat transfer.

Fan energy use can be calculated using the following formula:

Fan Energy $(\mathrm{kW})=$ (pressure drop) $\times$ (Air Flow Rate) / 6350(Fan Efficiency $x$ Motor Efficiency). 
Cooling energy savings in $\mathrm{kW}$ can be calculated using the following formula:

Cooling Energy $=($ Fouling Loss $\% \times$ Cooling load $) /(3413 \times$ Coefficient of Performance)

The cooling load posed by the surface fouling can be found in the manufacturer's performance specifications, with losses as high as $20 \%$. The coefficient of performance of a new unit operates with efficiency in the 2.6 to 3.0 range. The operating costs for the UV light treatment are the cost of electricity and the replacement cost of the UV lamps. These costs are typically much less than the cost of cleaning the coils. Table 2 itemizes the energy use that can be avoided.

Premium Efficiency Motors: Many utilities offer incentives for improving motor efficiency, installing adjustable speed drives, or improving overall motor system efficiency. A summary of incentive programs is available on the Motor Decisions Matter web site, www.motorsmatter.org. For more information, check with the local utility, the state energy office, or regional energy efficiency group. Manufacturers may also offer incentives for purchasing premium efficiency motors.

Original equipment suppliers sometimes offer their products with a choice of motors. If the owner considers first-cost price alone and selects the cheapest option, it is likely that the equipment will be fitted with a motor with a lower efficiency.

An eQUEST energy model was developed and the annual energy savings are summarized in Table 2. The energy efficiency measure wizard in eQUEST includes an option to model motors with three efficiencies: standard, high, and premium. The baseline was modeled with standard efficiency motors, and the option selected for this estimate was premium efficiency motors. Motor energy usages estimated by this model include the air handling unit motors and the pump motors.

Premium efficiency motors are generally made to higher manufacturing standards and tighter quality controls than the standard efficiency motors they are meant to replace. Premium efficiency motors run cooler because they generate less heat, thus producing less stress on windings. This lower stress is generally an indication that the motors will last longer, and it can translate to reduced downtime and lower repair costs over the life of the motor.

Variable Air Volume (VAV) Static Pressure Reset: Air static pressure in a VAV air handling system is normally maintained by modulating the speed of the fan. Air is distributed throughout the building by ductwork, and VAV terminal boxes control the flow of cool air delivered to the space they serve. As the space cooling load increases, the flow of cold air likewise increases to maintain the space temperature. If space cooling loads decrease, the requirements for cold air flow to cool the space also decrease. 
The air flow to the VAV terminal boxes is delivered at a system static pressure. The static pressure level is established by the minimum pressure required for the terminal boxes to deliver full cooling flows. During the winter, air flow requirements drop to their minimum levels and the static pressure required at terminal boxes decreases. This reduced air flow requirement brings about an opportunity to reduce the system static pressure levels along with reducing energy usage. Static pressure reset control strategies have been in use for more than 20 years and have been proven to provide significant levels of energy savings. California Title 24 also requires static pressure reset for VAV systems.

An eQUEST energy model was developed and the estimated annual energy savings is summarized in Table 2. The energy efficiency measure wizard option to model static pressure reset is not included in the current version of eQUEST. The magnitude of energy savings was estimated by modeling the baseline VAV system as a forward curved fan system with inlet vane dampers, and the static pressure reset option was modeled as a standard VAV system with variable speed drives.

Implementation of the improved air static pressure reset control can greatly increase the energy savings. Since 1999, American Society of Heating, Refrigerating and Air-Conditioning Engineers (ASHRAE) 90.1 has required that static air pressure be reset for systems with direct digital controls, "the setpoint is reset lower until one zone damper is nearly wide open." However, system design deficiencies often limit the potential energy savings. These design deficiencies create problem zones that cause the reset scheme to underperform because they frequently or constantly generate zone pressure increase requests.

\section{Common causes are:}

- Undersized VAV box because of improper selection in the design phase or unexpectedly high zone loads that are added to the space after construction;

- Cooling thermostat setpoint below design condition;

- Thermostats with heat releasing equipment under them (such as microwaves and coffee pots); and

- Air distribution design problems-high-pressure drop fittings or duct sections.

The first three items cause the zone to frequently demand maximum or nearmaximum zone air flow rates. Depending on zone location relative to the fan, a constant demand for high air flow rates indirectly causes the zone to generate frequent or constant pressure requests. The fourth problem directly results in pressure requests. For example: A zone with a fire/smoke damper installed in the 6-inch $(150 \mathrm{~mm})$ high-pressure duct at the box inlet. Small smoke dampers have little free area so pressure drop will be high.

Ways to mitigate the impact of problem zones on static pressure reset control sequences include: 
- Exclude the problem zones from the reset control sequence by literally ignoring the problem zone's pressure requests or including logic that ignores the first few pressure requests. Of course, ignoring the zone results in failure to meet zone air flow and temperature setpoints. This failure may be acceptable, however, if the zone is a problem because the temperature setpoint is too low, but it clearly can be an issue if the zone is more critical.

- Limit thermostat setpoint adjustments to a range that is close to space design temperatures. Direct digital control (DDC) systems typically have the ability to limit the range occupants can adjust setpoints from the thermostat. This limitation can prevent, for instance, cooling setpoints that are well below design conditions.

- Request that all thermostats are free of impact from appliances directly under thermostats.

- Fix duct restrictions/sizing issues. This option is clearly a better choice than ignoring the zone and letting it overheat, but the cost to make revisions may be higher that the owner is willing to invest. It is best, of course, to avoid these restrictions in the first place. For instance, the owner should avoid using flexible duct at VAV box inlets, avoid oversized inlet ducts when they extend a long way from the duct main, and avoid small fire/smoke dampers in VAV box inlet ducts.

- Add auxiliary cooling to augment the VAV zone. If the problem results from an undersized zone or unexpectedly high loads, a second cooling system, such as a split air conditioning (AC) system, can be added to supplement the VAV zone capacity. However, this solution is also expensive.

Demand-controlled Ventilation (DCV) using Carbon Dioxide $\left(\mathrm{CO}_{2}\right)$ Sensing: ASHRAE recommends a ventilation rate of 15 to 20 cubic feet per minute (cfm) per person in ASHRAE Standard 62-1999 to ensure adequate air quality in buildings. To meet the standard, many ventilation systems are designed to admit air at the maximum level whenever a building is occupied, as if every area were always at full occupancy. The result, in many cases, has been buildings that are highly over-ventilated. The development of $\mathrm{CO}_{2}$-based $\mathrm{DCV}$ was driven in part by the need to satisfy ASHRAE 62 without over-ventilating.

When $\mathrm{CO}_{2}$ sensors are used to maintain indoor air quality (IAQ), they continuously monitor the air in a conditioned space. Because people constantly exhale $\mathrm{CO}_{2}$, the difference between the indoor $\mathrm{CO}_{2}$ concentration and the outdoor concentration indicates the occupancy or activity level in a space and thus its ventilation requirements. An indoor/outdoor $\mathrm{CO}_{2}$ differential of 700 parts per million (ppm) is usually assumed to indicate a ventilation rate of 15 $\mathrm{cfm} /$ person; a differential of $500 \mathrm{ppm}$, or a $20 \mathrm{cfm} /$ person ventilation rate. The $\mathrm{CO}_{2}$ sensor readings are monitored at the air handling system control panel, which automatically increases ventilation when the $\mathrm{CO}_{2}$ concentration in a zone rises above a specified level. 
The highest payback can be expected in high-density spaces where occupancy is variable and unpredictable (such as auditoriums, some school buildings, meeting areas, and retail establishments), in locations with high heating or cooling demand (or both), and in areas with high utility rates. Case studies show DCV offers greater savings for heating than for cooling, however. In areas where peak power demand and peak prices are an issue, DCV can be used to control loads in response to real-time prices. DCV may result in significant cost savings even with little or no energy savings in those locations. Energy savings can be as high as $10 \%$. The potential energy cost savings for $\mathrm{CO}_{2}$-based $\mathrm{DCV}$ is estimated to be between $\$ 0.05$ to more than $\$ 1$ per square foot annually.

A report issued by the Department of Energy (DOE 2004) identified five case studies in large office buildings with $\mathrm{CO}_{2}$-based DCV, all of which reported energy savings that resulted in payback times of between 0.4 to 2.2 years. Two of the studies were computer simulations. One of those, conducted in 1994, simulated a 10-floor office building located in Miami, Atlanta, Washington D.C., New York, and Chicago. The simulation predicted large natural gas savings for heating and smaller electricity savings, resulting in predicted payback times for the different locations of between 1.4 to 2.2 years.

The DOE report (2004) cited an earlier study that modeled the impact of DCV and economizer operation on energy use in four building types (office, retail, restaurant, and school) in three locations representing different climates: Atlanta; Madison, Wisconsin; and Albuquerque. For cooling, predicted savings attributed to DCV depended greatly on location. Savings were larger with DCV in Atlanta and Madison because humidity made economizer operation less beneficial. In low-humidity Albuquerque, economizer operation was much more significant than DCV in reducing cooling energy demand. In all three locations, DCV resulted in large savings in heating energy for the office building - 27\% in Madison, 38\% in Albuquerque, and $42 \%$ in Atlanta; from $70 \%$ in Madison to more than $80 \%$ in Atlanta and Albuquerque for the school; and more than $90 \%$ in all three locations for the retail and restaurant spaces. Similar results were obtained for 17 other U.S. locations modeled. In all locations, the office building showed the most modest savings.

The reliability of $\mathrm{CO}_{2}$ sensors has improved in recent years, and they should be considered for use in the modern energy efficient office.

Estimated annual energy savings are summarized in Table 2. Energy savings were calculated by reducing the cooling and heating energy estimated by the baseline energy model by $20 \%$. A conservative estimate was used because of the unknown occupancy variations for this facility compared with the above case studies.

Chilled Water Reset: The minimum chilled water temperature of the chiller is needed when the cooling load is at its maximum. The load on the chiller and its efficiency are the lowest when the chiller is fully loaded and producing its coldest chilled water (often as cold as $41^{\circ} \mathrm{F}$ ). During periods of reduced loads, the cooling systems of the building are capable of meeting cooling requirements with 
chilled water as high as $54^{\circ} \mathrm{F}$. Many chilled water systems are operated at a constant chilled water supply temperature even though the cooling loads vary. Therefore, energy savings can be gained by resetting the chilled water supply temperature upward as the chiller load decreases. Generally, the chiller efficiency increases by about $1.5 \%$ for each degree increase in chilled-water temperature.

An eQUEST energy model was developed and the energy savings are summarized in Table 2. The energy efficiency measure wizard option in eQUEST includes an option for chilled water temperature reset control of chillers. The chilled water reset controlled by building loads was selected. Chilled water reset control strategies maintain the chilled water supply temperature (CHWST) at the setpoint, which ranges from $44^{\circ} \mathrm{F}$ to $54^{\circ} \mathrm{F}$, by modulating chiller capacity. The CHWST will have a default of $44^{\circ} \mathrm{F}$.

In a variable flow pumping system, the chilled water temperature will be reset upward only when the secondary pumps' speeds are at their minimum. They are reset upward only at this point because lowering pump speed with the differential pressure (DP) reset strategy competes with CHWST reset, but DP reset will save more energy than resetting the chilled water temperature up.

When the pump speed is at the minimum allowed, the CHWST reset routine is started and continues until one or more pumps are operating above their minimum speed, and then holds the CHWST setpoint at that level until the pumps return to their minimums. A differential or time delay is included to prevent excessive over response of the control logic. Likewise, the CHWST setpoint will not be reduced until all secondary pumps are at their maximum speed. This deference to the pressure reset is accomplished by starting the pressure reset downward when all coiling coil valves (CCVs) are less than $90 \%$ open and by not starting the CHWST reset upward until all CCVs are less than $80 \%$ open. When properly enabled, the CHWST reset sequence is when all CCV's are less than $80 \%$ open, the CHWST setpoint is at its highest value of a proportional range $\left(54^{\circ} \mathrm{F}\right)$; when three or more CCVs are $80 \%$ or more open, the CHWS setpoint is at its lowest value $\left(44^{\circ} \mathrm{F}\right)$.

Establish an Office Heating Setpoint of $70^{\circ} \mathrm{F}$ instead of $75^{\circ} \mathrm{F}$ : The energy model for the building developed by the design team has various setpoints for heating and cooling, and some of them do not match the setpoints stated in the summary of the Mechanical Design Data Handbook. However, if the heating set point of the building is $75^{\circ}$, the heating energy use will be significantly greater than if the setpoint is $70^{\circ} \mathrm{F}$.

An eQUEST energy model was developed and the annual estimated energy savings is summarized in Table 2. The energy efficiency measure wizard in eQUEST was used to model the savings for the heating setpoint.

Occupancy Sensor Controlled HVAC: Lighting occupancy sensors can be used to reduce the HVAC heating and cooling energy use in spaces that are not 
occupied. Temperatures in the unoccupied space are allowed to drift from occupied setpoints while the space is unoccupied. The state of the occupancy sensor is tapped by the building energy management system to control the heating or cooling setpoint of the space.

Energy savings can be estimated by extrapolating the savings from case studies of similar buildings. Office buildings with occupancy sensors controlling the lighting typically see savings of between 38 and $48 \%$. When the heating and cooling setpoints of the room are also controlled by the occupancy sensor, the HVAC savings will be less than the lighting energy savings because the ventilation system continues to provide minimum ventilation during the unoccupied periods. An example is an office that is unoccupied during a 2-week period while the occupant is on vacation. Even if this office was unoccupied during the winter, it would still need to be kept above some minimum temperature (typically no less than $55^{\circ} \mathrm{F}$ ).

Energy savings estimates included in Table 2 were calculated by reducing the cooling and heating energy from the baseline energy model by $10 \%$. A conservative estimate was used based on the unknown occupancy variations for this facility compared with the above case studies.

\subsection{Renewable Energy Measures Evaluated}

Several renewable energy measures were initially recommended, but were not ultimately accepted. These included installation of a solar thermal system to provide hot water for domestic hot water use and installation of wind power generation units instead of the metal shading planned for the courtyard. The latter item was a Broad Star wind system that uses an airplane wing design concept with a reported $30 \%$ greater efficiency than typical turbine systems. These systems can be sited in turbulent environments and produce low noise pollution while operating. Because of the low rotational speed of the turbine, radar interference is eliminated. 


\subsection{Potential Green House Gas Reduction}

The potential greenhouse gas emissions resulting from the energy savings was calculated based on the Environmental Protection Agency eGRID data (Pechan 2008). Based on the estimated savings of $170,944 \mathrm{kWh}$ and 443 therms, annual non-baseload $\mathrm{CO}_{2}$ emissions would be reduced by 124 metric tons. This calculation does not include any contribution that would be related to line losses. 


\subsection{Action Plan for Implementation of Energy Conservation Measures (ECMs)}

The goal of providing technical assistance to agencies is to provide them sufficient information so they can make informed decisions regarding implementation of the proposed measures. This takes the form of an action plan that identifies priorities and next steps, as well as identification of funding sources for onsite activities, capital equipments purchases, and the installation and operation of the proposed measures.

\subsection{Priorities and Next Steps}

The FAA has incorporated the recommended measures into the final design and operating specifications. They also indicated that they may consider other recommended measures, such as renewable projects, but a separate funding source would have to be identified and assistance required to obtain the funding.

The design review team also recommended that operating staff at the new building become familiar with the information contained in documents listed below so the installed equipment can be properly maintained to maximize the useful life of energy related equipment.

$\checkmark$ FEMP Retro-commissioning http://www1.eere.energy.gov/femp/pdf.om retrocs.pdf

$\checkmark$ FEMP Best Practices Operations and Maintenance http:///www1.eere.energy.gove/femp/operations maintenance/om bpguide.html

\subsection{Funding Assistance Available}

The selected measures are expected to be included in the overall cost to construct and operate the service building and the control tower. Thus, funding assistance is not required for this site. However, the local utility representative (PG\&E) should be contacted about potential available rebates available for installation of energy efficiency measures. 


\subsection{Assessment Team Members and Site Team}

Mr. Jim Arends, PE, CEM, of Redhorse Corporation completed the technical review of the design operating specification for the site. Mr. William Sandusky of PNNL was responsible for review of the technical report submitted by Redhorse and formatting of this document. 


\subsection{References}

Department of Energy (DOE). 2004. Federal Technology Alert: Demand Controlled Ventilation Using $\mathrm{CO}_{2}$ Sensors. DOE/EE-0293. Washington, DC. Can be accessed at http:/wwwl.eere.energy.gov/femp/pdfs/fta_co2.pdf.

E.H. Pechan \& Associates (Pechan). September 2008. The Emissions \& Generation Resource Integrated Database for 2007 (eGRID 2007). Report Number 08.09.006/9011.239. Springfield, Virginia. 


\section{APPENDIX A}

eQuest Modeling Results and Spreadsheet Calculations 



\section{Appendix A - eQUEST Modeling Results and Spreadsheet Calculations}

Energy modeling developed for the annual energy savings estimates were developed in eQUEST version 3.61. The schematic design model was used to develop the building footprint and input basic building systems. Basic model inputs include: 24 hours a day operation for 7 days a week, one variable volume air handler serving the majority of the base building, with the balance of the building served by constant volume air handling systems. The control tower provides air traffic controller space on the $8^{\text {th }}$ floor.

\section{Baseline eQUEST Model Results}

\begin{tabular}{|c|c|c|c|c|c|c|c|c|c|c|c|c|c|}
\hline \multicolumn{14}{|c|}{ Baseline eQUEST Results } \\
\hline \multicolumn{14}{|c|}{ Electric Consumption (kWh x000) } \\
\hline & Jan & Feb & Mar & Apr & May & Jun & Jul & Aug & Sep & Oct & Nov & Dec & Total \\
\hline Space Cool & 15.2 & 22.6 & 28.9 & 64.7 & 80.4 & 119 & 135.5 & 133.3 & 106.1 & 65.7 & 28.6 & 17.9 & 818.00 \\
\hline Heat Reject. & 0 & 0 & 0 & 0 & 0 & 0 & 0 & 0 & 0 & 0 & 0 & 0 & 0 \\
\hline Refrigeration & 0 & 0 & 0 & 0 & 0 & 0 & 0 & 0 & 0 & 0 & 0 & 0 & 0 \\
\hline Space Heat & 0 & 0 & 0 & 0 & 0 & 0 & 0 & 0 & 0 & 0 & 0 & 0 & 0 \\
\hline HP Supp. & 0 & 0 & 0 & 0 & 0 & 0 & 0 & 0 & 0 & 0 & 0 & 0 & 0 \\
\hline Hot Water & 0 & 0 & 0 & 0 & 0 & 0 & 0 & 0 & 0 & 0 & 0 & 0 & 0 \\
\hline Vent. Fans & 22 & 20.5 & 23.2 & 24.6 & 25.6 & 27.9 & 29.2 & 29.2 & 27 & 24.9 & 22.1 & 22.3 & 298.4 \\
\hline Pumps \& Aux. & 13.6 & 12.3 & 13.6 & 13.2 & 13.6 & 13.2 & 13.6 & 13.6 & 13.2 & 13.6 & 13.2 & 13.6 & 160.3 \\
\hline Ext. Usage & 0 & 0 & 0 & 0 & 0 & 0 & 0 & 0 & 0 & 0 & 0 & 0 & 0 \\
\hline Misc. Equip. & 170 & 164.4 & 193.9 & 185.7 & 176.1 & 185.9 & 181.6 & 187.9 & 180 & 175.9 & 173.9 & 181.8 & $2,157.00$ \\
\hline Task Lights & 0 & 0 & 0 & 0 & 0 & 0 & 0 & 0 & 0 & 0 & 0 & 0 & 0 \\
\hline Area Lights & 37.3 & 37 & 44.5 & 42.5 & 39.1 & 42.5 & 40.8 & 42.7 & 40.7 & 39.1 & 38.9 & 40.9 & 486 \\
\hline Total & 258 & 256.8 & 304.1 & 330.6 & 334.9 & 388.5 & 400.8 & 406.7 & 367 & 319.1 & 276.6 & 276.5 & $3,919.80$ \\
\hline \multicolumn{14}{|c|}{ Gas Consumption (Btu x000,000) } \\
\hline & Jan & Feb & Mar & Apr & May & Jun & Jul & Aug & Sep & Oct & Nov & Dec & Total \\
\hline Space Cool & 0 & 0 & 0 & 0 & 0 & 0 & 0 & 0 & 0 & 0 & 0 & 0 & 0 \\
\hline Heat Reject. & 0 & 0 & 0 & 0 & 0 & 0 & 0 & 0 & 0 & 0 & 0 & 0 & 0 \\
\hline Refrigeration & 0 & 0 & 0 & 0 & 0 & 0 & 0 & 0 & 0 & 0 & 0 & 0 & 0 \\
\hline Space Heat & 373 & 231.5 & 208.2 & 126.2 & 134.5 & 64.5 & 75.1 & 69.6 & 82.6 & 167.1 & 235.5 & 307.3 & $2,075.10$ \\
\hline HP Supp. & 0 & 0 & 0 & 0 & 0 & 0 & 0 & 0 & 0 & 0 & 0 & 0 & 0 \\
\hline Hot Water & 14.5 & 14.8 & 17.8 & 16.7 & 14.3 & 14 & 12.4 & 12.2 & 11.6 & 11.8 & 12.7 & 14.6 & 167.6 \\
\hline Vent. Fans & 0 & 0 & 0 & 0 & 0 & 0 & 0 & 0 & 0 & 0 & 0 & 0 & 0 \\
\hline Pumps \& Aux. & 0 & 0 & 0 & 0 & 0 & 0 & 0 & 0 & 0 & 0 & 0 & 0 & 0 \\
\hline Ext. Usage & 0 & 0 & 0 & 0 & 0 & 0 & 0 & 0 & 0 & 0 & 0 & 0 & 0 \\
\hline Misc. Equip. & 0 & 0 & 0 & 0 & 0 & 0 & 0 & 0 & 0 & 0 & 0 & 0 & 0 \\
\hline Task Lights & 0 & 0 & 0 & 0 & 0 & 0 & 0 & 0 & 0 & 0 & 0 & 0 & 0 \\
\hline Area Lights & 0 & 0 & 0 & 0 & 0 & 0 & 0 & 0 & 0 & 0 & 0 & 0 & 0 \\
\hline Total & 387.5 & 246.4 & 226 & 142.9 & 148.8 & 78.5 & 87.5 & 81.8 & 94.3 & 178.9 & 248.2 & 321.9 & $2,242.70$ \\
\hline
\end{tabular}


UV Energy Savings Calculations

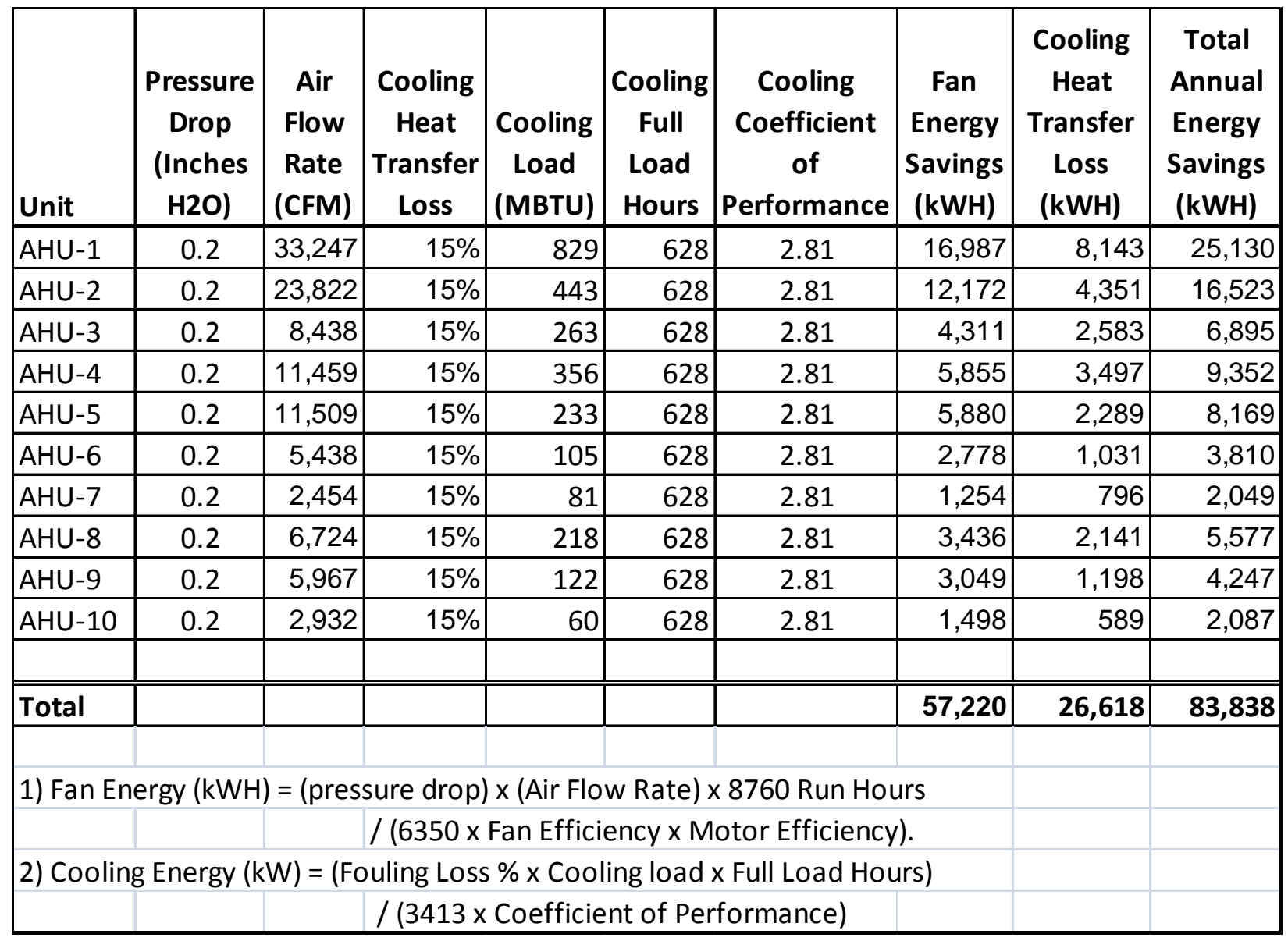




\section{Reheat Water Temperature Reset eQUEST Model Results}

eQUEST Heating Water Temperature Reset Results Electric Consumption (kWh x000)

\begin{tabular}{|c|c|c|c|c|c|c|c|c|c|c|c|c|c|}
\hline & Jan & Feb & Mar & Apr & May & Jun & Jul & Aug & Sep & Oct & Nov & Dec & Total \\
\hline Space Cool & 15.2 & 22.6 & 28.9 & 64.7 & 80.4 & 119 & 135.5 & 133.3 & 106.1 & 65.7 & 28.6 & 17.9 & 818.00 \\
\hline Heat Reject. & 0 & 0 & 0 & 0 & 0 & 0 & 0 & 0 & 0 & 0 & 0 & 0 & 0 \\
\hline Refrigeration & 0 & 0 & 0 & 0 & 0 & 0 & 0 & 0 & 0 & 0 & 0 & 0 & 0 \\
\hline Space Heat & 0 & 0 & 0 & 0 & 0 & 0 & 0 & 0 & 0 & 0 & 0 & 0 & 0 \\
\hline HP Supp. & 0 & 0 & 0 & 0 & 0 & 0 & 0 & 0 & 0 & 0 & 0 & 0 & 0 \\
\hline Hot Water & 0 & 0 & 0 & 0 & 0 & 0 & 0 & 0 & 0 & 0 & 0 & 0 & 0 \\
\hline Vent. Fans & 22 & 20.5 & 23.2 & 24.6 & 25.6 & 27.9 & 29.2 & 29.2 & 27 & 24.9 & 22.1 & 22.3 & 298.4 \\
\hline Pumps \& Aux. & 13.6 & 12.3 & 13.6 & 13.2 & 13.6 & 13.2 & 13.6 & 13.6 & 13.2 & 13.6 & 13.2 & 13.6 & 160.3 \\
\hline Ext. Usage & 0 & 0 & 0 & 0 & 0 & 0 & 0 & 0 & 0 & 0 & 0 & 0 & 0 \\
\hline Misc. Equip. & 170 & 164.4 & 193.9 & 185.7 & 176.1 & 185.9 & 181.6 & 187.9 & 180 & 175.9 & 173.9 & 181.8 & $2,157.00$ \\
\hline Task Lights & 0 & 0 & 0 & 0 & 0 & 0 & 0 & 0 & 0 & 0 & 0 & 0 & 0 \\
\hline Area Lights & 37.3 & 37 & 44.5 & 42.5 & 39.1 & 42.5 & 40.8 & 42.7 & 40.7 & 39.1 & 38.9 & 40.9 & 486 \\
\hline Total & 258 & 256.8 & 304.1 & 330.6 & 334.9 & 388.5 & 400.8 & 406.7 & 367 & 319.1 & 276.6 & 276.5 & $3,919.80$ \\
\hline
\end{tabular}

Gas Consumption (Btu x000,000)

\begin{tabular}{|c|c|c|c|c|c|c|c|c|c|c|c|c|c|}
\hline & & & & & & & & & & & & & \\
\hline & Jan & Feb & Mar & Apr & May & Jun & Jul & Aug & Sep & Oct & Nov & Dec & Total \\
\hline Space Cool & 0 & 0 & 0 & 0 & 0 & 0 & 0 & 0 & 0 & 0 & 0 & 0 & 0 \\
\hline Heat Reject. & 0 & 0 & 0 & 0 & 0 & 0 & 0 & 0 & 0 & 0 & 0 & 0 & 0 \\
\hline Refrigeration & 0 & 0 & 0 & 0 & 0 & 0 & 0 & 0 & 0 & 0 & 0 & 0 & 0 \\
\hline Space Heat & 373.1 & 231.7 & 208.4 & 126.4 & 134.6 & 64.5 & 75.2 & 69.7 & 82.7 & 167.2 & 235.8 & 307.4 & $2,076.60$ \\
\hline HP Supp. & 0 & 0 & 0 & 0 & 0 & 0 & 0 & 0 & 0 & 0 & 0 & 0 & 0 \\
\hline Hot Water & 14.5 & 14.8 & 17.8 & 16.7 & 14.3 & 14 & 12.4 & 12.2 & 11.6 & 11.8 & 12.7 & 14.6 & 167.6 \\
\hline Vent. Fans & 0 & 0 & 0 & 0 & 0 & 0 & 0 & 0 & 0 & 0 & 0 & 0 & 0 \\
\hline Pumps \& Aux. & 0 & 0 & 0 & 0 & 0 & 0 & 0 & 0 & 0 & 0 & 0 & 0 & 0 \\
\hline Ext. Usage & 0 & 0 & 0 & 0 & 0 & 0 & 0 & 0 & 0 & 0 & 0 & 0 & 0 \\
\hline Misc. Equip. & 0 & 0 & 0 & 0 & 0 & 0 & 0 & 0 & 0 & 0 & 0 & 0 & 0 \\
\hline Task Lights & 0 & 0 & 0 & 0 & 0 & 0 & 0 & 0 & 0 & 0 & 0 & 0 & 0 \\
\hline Area Lights & 0 & 0 & 0 & 0 & 0 & 0 & 0 & 0 & 0 & 0 & 0 & 0 & 0 \\
\hline Total & 387.6 & 246.5 & 226.2 & 143.1 & 148.9 & 78.6 & 87.6 & 81.9 & 94.4 & 179 & 248.5 & 322 & $2,244.20$ \\
\hline
\end{tabular}




\section{Supply Air Temperature Reset eQUEST Model Results}

\begin{tabular}{|c|c|c|c|c|c|c|c|c|c|c|c|c|c|}
\hline \multicolumn{14}{|c|}{ eQUEST Supply Air Temperature Reset Results } \\
\hline \multicolumn{14}{|c|}{ Electric Consumption (kWh x000) } \\
\hline & Jan & Feb & Mar & Apr & May & Jun & Jul & Aug & Sep & Oct & Nov & Dec & Total \\
\hline Space Cool & 12.2 & 16.6 & 23 & 57.2 & 72.1 & 115.8 & 130.6 & 129 & 101.6 & 56.6 & 21.7 & 14.7 & 750.90 \\
\hline Heat Reject. & 0 & 0 & 0 & 0 & 0 & 0 & 0 & 0 & 0 & 0 & 0 & 0 & 0 \\
\hline Refrigeration & 0 & 0 & 0 & 0 & 0 & 0 & 0 & 0 & 0 & 0 & 0 & 0 & 0 \\
\hline Space Heat & 0 & 0 & 0 & 0 & 0 & 0 & 0 & 0 & 0 & 0 & 0 & 0 & 0 \\
\hline HP Supp. & 0 & 0 & 0 & 0 & 0 & 0 & 0 & 0 & 0 & 0 & 0 & 0 & 0 \\
\hline Hot Water & 0 & 0 & 0 & 0 & 0 & 0 & 0 & 0 & 0 & 0 & 0 & 0 & 0 \\
\hline Vent. Fans & 24.6 & 23.7 & 27.2 & 28.9 & 30 & 32.8 & 34.2 & 34.2 & 31.6 & 28.9 & 25.6 & 25.4 & 347.2 \\
\hline Pumps \& Aux. & 13.6 & 12.3 & 13.6 & 13.2 & 13.6 & 13.2 & 13.6 & 13.6 & 13.2 & 13.6 & 13.2 & 13.6 & 160.3 \\
\hline Ext. Usage & 0 & 0 & 0 & 0 & 0 & 0 & 0 & 0 & 0 & 0 & 0 & 0 & 0 \\
\hline Misc. Equip. & 170 & 164.4 & 193.9 & 185.7 & 176.1 & 185.9 & 181.6 & 187.9 & 180 & 175.9 & 173.9 & 181.8 & $2,157.00$ \\
\hline Task Lights & 0 & 0 & 0 & 0 & 0 & 0 & 0 & 0 & 0 & 0 & 0 & 0 & 0 \\
\hline Area Lights & 37.3 & 37 & 44.5 & 42.5 & 39.1 & 42.5 & 40.8 & 42.7 & 40.7 & 39.1 & 38.9 & 40.9 & 486 \\
\hline Total & 257.6 & 254 & 302.1 & 327.5 & 331 & 390.2 & 400.8 & 407.4 & 367 & 314.1 & 273.2 & 276.4 & $3,901.40$ \\
\hline \multicolumn{14}{|c|}{ Gas Consumption (Btu x000,000) } \\
\hline & Jan & Feb & Mar & Apr & May & Jun & Jul & Aug & Sep & Oct & Nov & Dec & Total \\
\hline Space Cool & 0 & 0 & 0 & 0 & 0 & 0 & 0 & 0 & 0 & 0 & 0 & 0 & 0 \\
\hline Heat Reject. & 0 & 0 & 0 & 0 & 0 & 0 & 0 & 0 & 0 & 0 & 0 & 0 & 0 \\
\hline Refrigeration & 0 & 0 & 0 & 0 & 0 & 0 & 0 & 0 & 0 & 0 & 0 & 0 & 0 \\
\hline Space Heat & 78.14 & 28.88 & 20.87 & 2.98 & 0.47 & 0 & 0 & 0 & 0 & 5.78 & 24.33 & 51.33 & 212.76 \\
\hline HP Supp. & 0 & 0 & 0 & 0 & 0 & 0 & 0 & 0 & 0 & 0 & 0 & 0 & 0 \\
\hline Hot Water & 14.46 & 14.84 & 17.81 & 16.68 & 14.26 & 14.03 & 12.42 & 12.22 & 11.62 & 11.77 & 12.73 & 14.59 & 167.42 \\
\hline Vent. Fans & 0 & 0 & 0 & 0 & 0 & 0 & 0 & 0 & 0 & 0 & 0 & 0 & 0 \\
\hline Pumps \& Aux. & 0 & 0 & 0 & 0 & 0 & 0 & 0 & 0 & 0 & 0 & 0 & 0 & 0 \\
\hline Ext. Usage & 0 & 0 & 0 & 0 & 0 & 0 & 0 & 0 & 0 & 0 & 0 & 0 & 0 \\
\hline Misc. Equip. & 0 & 0 & 0 & 0 & 0 & 0 & 0 & 0 & 0 & 0 & 0 & 0 & 0 \\
\hline Task Lights & 0 & 0 & 0 & 0 & 0 & 0 & 0 & 0 & 0 & 0 & 0 & 0 & 0 \\
\hline Area Lights & 0 & 0 & 0 & 0 & 0 & 0 & 0 & 0 & 0 & 0 & 0 & 0 & 0 \\
\hline Total & 92.6 & 43.71 & 38.68 & 19.66 & 14.72 & 14.03 & 12.42 & 12.22 & 11.62 & 17.55 & 37.05 & 65.92 & 380.18 \\
\hline
\end{tabular}


Static Pressure Reset eQUEST Model Results

\begin{tabular}{|c|c|c|c|c|c|c|c|c|c|c|c|c|c|}
\hline \multicolumn{14}{|c|}{ eQUEST Static Pressure Reset Results } \\
\hline \multicolumn{14}{|c|}{ Electric Consumption (kWh x000) } \\
\hline & Jan & Feb & Mar & Apr & May & Jun & Jul & Aug & Sep & Oct & Nov & Dec & Total \\
\hline Space Cool & 14.8 & 21.7 & 27.9 & 63.2 & 78.8 & 117.2 & 133.4 & 131.1 & 104.4 & 64 & 27.5 & 17.4 & 801.50 \\
\hline Heat Reject. & 0 & 0 & 0 & 0 & 0 & 0 & 0 & 0 & 0 & 0 & 0 & 0 & 0 \\
\hline Refrigeration & 0 & 0 & 0 & 0 & 0 & 0 & 0 & 0 & 0 & 0 & 0 & 0 & 0 \\
\hline Space Heat & 0 & 0 & 0 & 0 & 0 & 0 & 0 & 0 & 0 & 0 & 0 & 0 & 0 \\
\hline HP Supp. & 0 & 0 & 0 & 0 & 0 & 0 & 0 & 0 & 0 & 0 & 0 & 0 & 0 \\
\hline Hot Water & 0 & 0 & 0 & 0 & 0 & 0 & 0 & 0 & 0 & 0 & 0 & 0 & 0 \\
\hline Vent. Fans & 14.7 & 14 & 16.1 & 18 & 18.8 & 21.8 & 23 & 22.9 & 20.7 & 18 & 15.1 & 15.1 & 218.2 \\
\hline Pumps \& Aux. & 13.6 & 12.3 & 13.6 & 13.2 & 13.6 & 13.2 & 13.6 & 13.6 & 13.2 & 13.6 & 13.2 & 13.6 & 160.3 \\
\hline Ext. Usage & 0 & 0 & 0 & 0 & 0 & 0 & 0 & 0 & 0 & 0 & 0 & 0 & 0 \\
\hline Misc. Equip. & 170 & 164.4 & 193.9 & 185.7 & 176.1 & 185.9 & 181.6 & 187.9 & 180 & 175.9 & 173.9 & 181.8 & $2,157.00$ \\
\hline Task Lights & 0 & 0 & 0 & 0 & 0 & 0 & 0 & 0 & 0 & 0 & 0 & 0 & 0 \\
\hline Area Lights & 37.3 & 37 & 44.5 & 42.5 & 39.1 & 42.5 & 40.8 & 42.7 & 40.7 & 39.1 & 38.9 & 40.9 & 486 \\
\hline Total & 250.3 & 249.4 & 296 & 322.6 & 326.4 & 380.6 & 392.4 & 398.3 & 359 & 310.6 & 268.6 & 268.8 & $3,823.00$ \\
\hline
\end{tabular}

Gas Consumption (Btu x000,000)

\begin{tabular}{|c|c|c|c|c|c|c|c|c|c|c|c|c|c|}
\hline 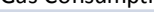 & & & & & & & & & & & & & \\
\hline & Jan & Feb & Mar & Apr & May & Jun & Jul & Aug & Sep & Oct & Nov & Dec & Total \\
\hline Space Cool & 0 & 0 & 0 & 0 & 0 & 0 & 0 & 0 & 0 & 0 & 0 & 0 & 0 \\
\hline Heat Reject. & 0 & 0 & 0 & 0 & 0 & 0 & 0 & 0 & 0 & 0 & 0 & 0 & 0 \\
\hline Refrigeration & 0 & 0 & 0 & 0 & 0 & 0 & 0 & 0 & 0 & 0 & 0 & 0 & 0 \\
\hline Space Heat & 372.9 & 232 & 208.5 & 127 & 135.4 & 64.9 & 75.6 & 70 & 83.2 & 168 & 235.9 & 307.3 & $2,080.60$ \\
\hline HP Supp. & 0 & 0 & 0 & 0 & 0 & 0 & 0 & 0 & 0 & 0 & 0 & 0 & 0 \\
\hline Hot Water & 14.5 & 14.8 & 17.8 & 16.7 & 14.3 & 14 & 12.4 & 12.2 & 11.6 & 11.8 & 12.7 & 14.6 & 167.6 \\
\hline Vent. Fans & 0 & 0 & 0 & 0 & 0 & 0 & 0 & 0 & 0 & 0 & 0 & 0 & 0 \\
\hline Pumps \& Aux. & 0 & 0 & 0 & 0 & 0 & 0 & 0 & 0 & 0 & 0 & 0 & 0 & 0 \\
\hline Ext. Usage & 0 & 0 & 0 & 0 & 0 & 0 & 0 & 0 & 0 & 0 & 0 & 0 & 0 \\
\hline Misc. Equip. & 0 & 0 & 0 & 0 & 0 & 0 & 0 & 0 & 0 & 0 & 0 & 0 & 0 \\
\hline Task Lights & 0 & 0 & 0 & 0 & 0 & 0 & 0 & 0 & 0 & 0 & 0 & 0 & 0 \\
\hline Area Lights & 0 & 0 & 0 & 0 & 0 & 0 & 0 & 0 & 0 & 0 & 0 & 0 & 0 \\
\hline Total & 387.4 & 246.8 & 226.3 & 143.7 & 149.7 & 78.9 & 88 & 82.3 & 94.8 & 179.7 & 248.6 & 321.9 & $2,248.10$ \\
\hline
\end{tabular}

\section{Occupancy Sensor HVAC eQUEST Calculation}

\begin{tabular}{|l|r|r|r|r|r|}
\hline & $\begin{array}{c}\text { Baseline } \\
\text { Electrical } \\
\text { Use } \\
\text { (kWh) }\end{array}$ & $\begin{array}{c}\text { Baseline } \\
\text { Natural } \\
\text { Gas Use } \\
\text { (therms) }\end{array}$ & $\begin{array}{c}\text { Typical } \\
\text { Savings }\end{array}$ & $\begin{array}{c}\text { Cooling } \\
\text { Savings } \\
\text { (kWh) }\end{array}$ & $\begin{array}{c}\text { Heating } \\
\text { Savings } \\
\text { (therms) }\end{array}$ \\
\hline $\begin{array}{l}\text { Cooling and Heating Energy } \\
\text { Use }\end{array}$ & 818,000 & 2,075 & $10.0 \%$ & 81,800 & 208 \\
\hline
\end{tabular}

Exhaust Air Heat Recovery Calculations

\begin{tabular}{|l|r|r|r|r|r|}
\hline $\begin{array}{l}\text { eQUEST Energy Model } \\
\text { Runs }\end{array}$ & $\begin{array}{c}\text { Baseline } \\
\text { Electrical } \\
\text { Use } \\
\text { (kWh) }\end{array}$ & $\begin{array}{c}\text { Baseline } \\
\text { Natural } \\
\text { Gas Use } \\
\text { (therms) }\end{array}$ & $\begin{array}{c}\text { Typical } \\
\text { Energy } \\
\text { Recovery } \\
\text { Savings }\end{array}$ & $\begin{array}{c}\text { Cooling } \\
\text { Savings } \\
\text { (kWh) }\end{array}$ & $\begin{array}{c}\text { Heating } \\
\text { Savings } \\
\text { (therms) }\end{array}$ \\
\hline $\begin{array}{l}\text { Cooling and Heating Energy } \\
\text { Use }\end{array}$ & 818,000 & 2,075 & $20.0 \%$ & 163,600 & 415 \\
\hline
\end{tabular}


